Association for Information Systems AIS Electronic Library (AISeL)

PACIS 2005 Proceedings

Pacific Asia Conference on Information Systems

(PACIS)

December 2005

\title{
Organizational Culture and Leadership in ERP Implementation
}

Weiling Ke

Clarkson University

Kwok-Kee Wei

City University of Hong Kong

Follow this and additional works at: http://aisel.aisnet.org/pacis2005

\section{Recommended Citation}

Ke, Weiling and Wei, Kwok-Kee, "Organizational Culture and Leadership in ERP Implementation" (2005). PACIS 2005 Proceedings. 35 .

http://aisel.aisnet.org/pacis2005/35

This material is brought to you by the Pacific Asia Conference on Information Systems (PACIS) at AIS Electronic Library (AISeL). It has been accepted for inclusion in PACIS 2005 Proceedings by an authorized administrator of AIS Electronic Library (AISeL). For more information, please contact elibrary@aisnet.org. 


\title{
Organizational Culture and Leadership in ERP Implementation
}

\author{
Weiling Ke \\ School of Business \\ Clarkson University \\ wke@clarkson.edu
}

\author{
Kwok Kee Wei \\ Department of Information Systems \\ City University of Hong Kong \\ isweikk@cityu.edu.hk
}

\begin{abstract}
In response to the call for research to unlock the mystery of benefit realization in ERP adoption and theorize the important predictors' effect on ERP implementation, we conduct this study. In this paper, we intend to theorize how leadership affects ERP implementation through fostering the desire organizational culture, in addition to its direct effect. We contend that ERP adoption success is positively related with the dimensions of organizational culture including learning and development, participating decision making, power sharing, comprehensive and cross-functional communication, and tolerance for risk and conflicts. In addition, we identify the strategic and tactical conducts that the top management can take to influence culture and foster the desired culture conducive to ERP implementation. The theoretical contributions and managerial implication of this study are discussed.
\end{abstract}

Keywords: Leadership, Organizational Culture, ERP implementation

\section{Introduction}

Enterprise resource planning system (ERP), as a type III IS innovation, has strategic relevance for the firm because their integration into the core business processes or strategies can directly impact the firm's performance (Swanson 1994; Sambamurthy et al. 2003; Sample 1998). Thus, many firms have begun to develop strategies focusing on information technologies, with ERP adoption being a critical thrust (Bharadwaj 2000; Powell and Dent-Micallef 1997; Robey et al. 2002). However, while the firm is seeking to derive competitive advantages by adopting this advanced information system, the actual experiences have exhibited ambiguity - while some firms achieve successful outcomes with regard to their ERP adoption, more firms fall victim to the long costly unsuccessful adoption process and find the promising benefits far beyond reach (Scott and Vessey 2000). According to the survey conducted by Deloitte, the success rate of ERP implementation is less than $20 \%$. Hence it is important for researcher to unlock the mystery of benefit realization in ERP adoption and theorize the important predictors' effect on ERP implementation practice (Brown and Vessey 2003).

The literature suggests that the fit between the information system and organizational culture is critical for the firm to reap potential benefits promised by the system (Romm et al. 1991). For example, Martinsons and Chong (1999) note that "even good technology can be sabotaged if it is perceived to interfere with the established social network (p. 124)". Their finding is supported by Cooper (1994), who suggests that when IT conflicts with an organization's culture, the implementation will be resisted in one of two ways - either the system will be rejected or it will be modified so that it matches the existing culture. On the other hand, there is a strong body of opinion that culture can be consciously designed and manipulated (e.g., Schein 1985; Block 2003) and leadership is a necessary factor in this process (Senge 1990; Vera and Crossan 2004; Waldman et al. 2001). Hence leadership can enhance the chance of ERP implementation success by fostering a desired culture, in addition 
to its direct effect on ERP adoption. Indeed, in the extant ERP literature, the role played by top management, its leadership in particular, is consistently identified as the most important factor affecting the ERP implementation (e.g., Sarker and Lee 2000; Umble et al. 2003; Al-Mudimigh et al. 2001; Bingi et al. 1999), though mediating role of culture is not stated explicitly. Unfortunately, there is no study on the mediating role of organizational culture in the relationship between leadership and ERP implementation success and how leadership can foster an organizational culture conducive to ERP implementation.

We intend to theorize how leadership affects ERP implementation through fostering the right organizational culture. We do not attempt a comprehensive or exhaustive discussion here. Rather, we offer initial direction and propositions to spur research efforts. In particular, we study the dimensions of organizational culture relevant to ERP implementation, i.e., learning and development, participating decision making, power sharing, comprehensive and cross-functional communication, support and collaboration and tolerating risk and conflicts. We argue that ERP implementation success is positively related with these dimensions of organizational culture. In addition, focusing on the leadership at the top management level, we identify the strategic and tactical conducts that can be taken to influence organizational culture and theorize how these conducts can foster the desired culture conducive to ERP implementation.

This paper is organized as follow. First, we briefly review the literature relevant to the concept of enterprise system, organizational culture and leadership. We then describe the theoretical framework and articulate our propositions on the relationships between strategic and tactical conducts of leadership, organizational culture attributes and ERP implementation success. The last is our discussion and conclusion.

\section{Literature Review}

\subsection{Enterprise Resource Planning System}

ERP systems have been defined as "comprehensive, packaged software solution that seeks to integrate the complete range of a business' processes and functions in order to present a holistic view of the business from a single information and IT architecture" (Gable 1998, p. 2 ). By integrating the business processes across the organization and the central database, ERP differs from earlier information systems in its capacity to disseminate information in real-time and increase organizational flexibility and agility (Sambamurthy et al. 2002; Markus et al. 2000). In addition, embedded within the ERP package are best business models that their designers believe to represent best practices. Thus, ERP provides the organization windows of opportunity for strategic changes. However, due to the integration of large scale, ERP implementation is a complex and highly inter-dependent task (Sharma and Yetton 2003). Also, the possible conflicts between the existing organizational culture and the culture assumption embedded in the ERP system escalates the difficulties of ERP implementation and makes ERP project prone to fail. According to the survey conducted by Deloitte, the rate of on-time and within budget ERP implementation is less than $20 \%$. We expect that the rate of adopting organizations' realizing potential benefits of ERP is even lower.

\subsection{Organizational Culture}

Organizational culture is defined typically in terms of the way people think, which has a direct influence on the ways in which they behave. For example, recognizing that culture manifests itself in terms of behavior and espoused values, Schein (1998) suggests that the essence of culture lies in the set of "underlying assumptions." Similarly, Deshpande and Webster (1989, p.4) define organizational culture as a "set of shared assumptions and 
understanding about organization functioning." The theoretical argument about culture is that it is a complex system of norms and values that is shaped over time (Schein 1985). It is generally understood as the social glue that holds organizational members together and expresses the values, social ideals, and beliefs that members share. A firm's culture therefore, through its values and operating beliefs, exerts commanding influences on how its employees perceive events (Denison and Mishra 1995) and how they behave (Schein 1985, Barney 1986).

Organizational culture is known to be important for the success of projects involving organizational changes. For example, Martinsons and Chong (1999) note that "even good technology can be sabotaged if it is perceived to interfere with the established social network (p. 124)". Their finding was supported by Cooper (1994), who suggests that when IT conflicts with an organization's culture, the implementation will be resisted in one of two ways - either the system will be rejected or it will be modified so that it matches the existing culture. In the context of ERP implementation, Kampmeier (1998) states that one reason for many ERP failures is that we pay insufficient attention to the organizational culture. Similarly, Schneider (1999) reports that many companies' suffering from their ERP projects is because of their ignoring organizational culture in the rush to implement this complex system. A fit between organizational culture and the cultural assumption embedded in ERP is critical for ERP implementation success. Unfortunately, there is a lack of study on how organizational culture affects ERP implementation and how the organization can foster an organization culture conducive to ERP implementation.

\subsection{Leadership}

Leadership is defined as the use of non-coercive influences to direct and coordinate the activities of group members toward goal attainment (McLean and Smits, 2003). Based on how leaders motivate followers, we can classify leadership into two categories transformational leadership and transactional leadership (Pawar and Eastman, 1997; Bass 1985). Transactional leadership is based on the notion that the relationship between leaders and followers is a form of transaction, with the assumption that people are basically instrumental and calculative. Transactional leaders are individuals being sensitive to the needs of others, who follow them in return for the satisfaction of these needs (Jung and Avolio, 1999; Waldman et al. 2001). Thus, transactional leadership is based on linking efforts to rewards in followers' mind, setting patterns of desired behavior and keeping the followers on task throughout the process. By contrast, transformational leaders are those who "by the force of their personal abilities are capable of having profound and extraordinary effects on followers" (House and Baetz, 1979, p. 399). Based on followers' emotion, transformational leaders motivate their followers to efforts that "go above and beyond" the instrumental returns promised/delivered by transactional leaders, i.e., the organizational citizen behaviors (Klein and House, 1995; Smith et al. 1983; Borman and Motowidlo 1997; Podsakoff and Mackenzie 1997). Thus, the closer relationship between transformational leaders and followers is based more on trust and commitment than on contractual agreements (Gardner and Avolio, 1998).

Early leadership research has focused on transformational leadership and identified it as a necessary factor for organizational changes. However, recent studies suggest that it is not enough to sustain large-system changes. To maintain patterns of desired behavior over time, transactional leadership is needed (Waldman et al. 2001; Vera and Crossan 2004). Indeed, meta-analytic evidence provides overall support for the performance-stimulating potential of transactional leadership and even stronger support for that of transformational leadership 
(Lowe et al. 1996). Thus, transformation and transactional leadership are complementary to each other and can be operated in tandem.

Literature suggests that leadership is crucial for the effectiveness of IT adoption and organizational culture changes (e.g., Fiol and Lyles 1985; Ulrich et al. 1993; Lahteenmaki et al. 2001; Senge 1990; Vera and Crossan 2004; Waldman et al. 2001). The IS literature suggests that leaders' vision, attitude and behavior are critical for employees' perceptions of IT innovation and thus its adoption outcomes (Purvis et al. 2001; Boynton et al. 1994; Armstrong and Sambamurthy 2001; Orlikowski 1992; McKenney et al. 1997). In the context of ERP implementation, leadership is consistently found to be the most important factor leading to ERP implementation success (e.g., Sarker and Lee 2003; Umble et al. 2003; Al-Mudimigh et al. 2001; Bingi et al. 1999). Unfortunately, there is a lack of study on the underlying process of how leadership influences ERP implementation. According to literature in management, leadership's effects on organizational changes are mediated by organizational culture (Ogbonna and Harris 2000) and this culture can be consciously designed and manipulated by leadership (Senge 1990; Vera and Crossan 2004; Waldman et al. 2001; Schein 1985; Block 2003). Hence we perceive that leadership in ERP adopting organizations can proactively foster an organizational culture conducive to ERP implementation and thereby enhance ERP success.

\section{Theoretical Model}

While previous research has acknowledged the critical role of leadership in ERP adoption and the importance of the fit between organizational culture and ERP's management philosophy, there is still a lack of study on the integration of these three important constructs, especially how leadership influences organizational culture and fosters the culture conducive to ERP adoption. Thus, our intent is to build on prior research in leadership, organizational culture and ERP implementation to propose explicit relationships between these three constructs. We do not attempt a comprehensive or exhaustive discussion here. Rather, we offer initial direction and propositions to spur research efforts.

Implementation of ERP follows various stages of IS implementation as suggested by stage models (Kwon and Zmud 1987). Most ERP researches focus on on-time and/or within budget implementation. ERP assimilation - the effective application of ERP in supporting, shaping and enabling firms' business strategies and value-chain activities - needs to be considered due to few study o it. The study on assimilating ERP is more meaningful due to the significant benefits that may be derived only after the organization applies ERP effectively. Hence, we define ERP implementation success as the effectiveness of ERP application by the adopting organization.

Organizational culture is defined as a set of commonly-held values, beliefs and assumptions within an organization. This set of underlying beliefs influence employees' perceptions and behavior. With its own specific culture, every organization has its own unique practices dealing with organizational changes (Schein 1985). The implementation of an ERP is likely to produce widespread organizational changes because of its scope. The organization's existing culture is therefore likely to have profound effects on the ERP implementation process. Hence organizational culture exerts a powerful influence on how the firm implements ERP, which provides the firm windows of opportunity for strategic changes.

Organizational culture can be characterized by the kinds of behavior that are valued and promoted in the organization. Following Hurley and Hult (1998), we characterize 
organizational culture along the dimensions of learning and development, participative decision making, support and collaboration, power sharing, communication and tolerance for conflict and risk. Learning and development refers to an emphasis on individual learning and development; participative decision making culture encourages employees to participate in the firm's decision-making process; a culture of support and collaboration has employees willing to cooperation with each other and ready to offer needed help; power sharing reduces focus on turf, politics, and status; communication refers to the organization's internal and external information exchange and interaction; tolerance for conflict and risk taking measures the degree to which the organization accepts conflict and risk.

ERP integrates business processes and information systems across functional silos. Its implementation involves business process reengineering and system configuration, which requires the organization to take risk and be innovative in designing new business practices in the light of ERP's functionalities. These innovative ideas come from the individual employees. An organizational culture of learning and development enhances employees' creativity and ability to notice novel opportunities. Also, there may be contradiction and conflicts of interests in the reengineering process. A culture tolerating and resolving conflicts is critical for ERP implementation success. Moreover, ERP empowers the employees at the front line to make ad hoc decisions in response to market changes and be responsible for their behavior. Hence ERP implementation success is related with a culture of high tolerance for conflict and risk.

Proposition la ERP implementation success is positively related with the organization's learning and development culture.

Proposition $1 b \quad$ ERP implementation success is positively related with the organization's tolerance for conflict and risk.

Due to its scope and integrating nature, ERP implementation is very complex and requires the marriage of business and system knowledge located in different functional units. An organizational culture characterized as supportive and collaborative can reduce employees' fear and increase their openness in sharing their knowledge with other departments. Such an culture also signals to employees that they are valued, which encourages them to care about ERP implementation for the good of the organization. Hence the culture of support and collaboration enhances ERP implementation success. ERP implementation is also a process of information and knowledge sharing and integration. Thus, the organizational culture promoting the free-flow of information and sharing of knowledge among employees and across department lines is important for ERP implementation success. In addition, in the process of reaching consensus on the new set of business processes, compromising individuals and groups' interests for the good or the whole organization is necessary. A culture of power sharing aides the acceptance of new business processes, in addition to facilitating collaboration and sharing of information and resources needed by ERP implementation. Furthermore, participative decision making increases employees' involvement and commitment to innovate in long-lasting ERP project - usually for years, in addition to increasing their perceived freedom to act and innovate.

Proposition 1c ERP implementation success is positively related with the organization's support and collaboration.

Proposition 1d ERP implementation success is positively related with the organization's comprehensive and cross-functional communication. 
Proposition le ERP implementation success is positively related with the organization's power sharing.

Proposition If ERP implementation success is positively related with the organization's participative decision making.

Organizational culture has been identified as the main factor affecting firm's ERP implementation (Martinsons and Chong, 1999; Cooper 1994), and therefore leaders should model the proper behaviors causing culture to evolve in a way that facilitates ERP implementation. Leadership is a relationship in which leaders influence followers. It can foster an organization culture that fits ERP management philosophy and implementation requirement, i.e., a culture that enables and motivates employees to generate innovative ideas, openly share their information and knowledge, readily to support and collaborate with others within and across departments, be willing to participate in decision making and share power, and tolerate conflicts and risk. Leadership leading to such culture deals with knowledge workers having specialized expertise and thus is referred to as 'leading through a knowledge lens'. Leading is done by intellectual power, conviction, persuasion, and interactive dialog. It requires mechanisms that build confidence and engagement and foster trust and commitment. These mechanisms include leaders' strategic and tactical conducts, such as formulating a strategic vision, strong advocacy of the vision, role modeling, creating intellectual stimulation and setting up right structures to facilitate communication.

A critical part of leader's agenda is to formulate a vision, including the firm's strategic IT vision. Following Zmud (1988), we define strategic vision as the shared, aspired state of the role that IT should play in the firm. It evokes organizational images of the role that IT will play in the firms' business activities and competitive strategies. ERP can be regarded as a means to automate, informate up, informate down or transform the organization (Scott-Morton 1991; Doty et al. 1993). With the vision of automate, the firm aims to enhance its operation efficiency. ES adoption is shaped as a reaction to key business needs for cost control/avoidance and is regarded as an expense that must be carefully managed (Armstrong and Sambamurthy 2001). This vision curtails the amount of slack resources that can be dedicated to ERP project and discourages the exploration of better business processes in the light of ERP capabilities. By contrast, the firm with a transform vision views ES to be a key driver of its value proposition and ES initiative is more likely to be considered critical organizational resource (Armstrong and Sambamurthy 2001). Achieving strategic renewal in the light of ERP functionalities, rather than cost saving, becomes the primary concern. This vision leads the firm to allocate more slack resources to the ERP project and take higher risk. The resources allow the firm to take risk and try out different ways of improving business processes and thereby encourage employees to generate innovative ideas. Hence in addition to facilitate the ERP implementation through allocating slack resources, the leader's transform vision of ERP helps to foster an organizational culture with high tolerance for risk.

Proposition $2 a \quad$ Leader's transform vision of ERP ensures enough resources dedicated to ERP project and enhances the change of ERP adoption success.

Proposition $2 b$ Leader's transform vision of ERP adoption helps to foster an organizational culture of high tolerance for risk.

Leadership allays follower concerns, generates confidence in ERP and inspires commitment to ERP project by its active advocacy of strategic ERP vision. Theories of technology innovation make it quite clear that potential adopters are likely to experience considerable ambiguity about the value of new technologies for their work (Weick 1990). The leader's 
vision is a source of psychological comfort for the followers (Bass 1985). When ERP is first introduced, there are doubts or even misgivings among followers regarding this technology's perceived benefits and costs. By advocating their vision and explaining openly the rationale for ERP adoption, the top management team equips followers with conceptual knowledge of ERP, such as the capabilities of ERP, its features, potential use, and cost and benefits (Rogers 1995). Thus, in addition to alleviating followers' stress, leaders' communicating ERP vision helps followers to feel the need of ERP adoption, which fosters followers' attitudinal commitment to the ERP project (Yukl 1998). Such commitment ensures followers' continuous support and enthusiasm for the proposed changes required by ERP assimilation, which is especially important for ERP project due to its high complexity and difficulty.

In addition, by active advocacy of their ERP vision, the leader achieves followers' alignment. The communication of the view on ERP adoption by top managers serves to signal the importance and legitimacy of the ERP assimilation. It helps to achieve the congruency of followers and leaders' interpretive orientations on their values of and beliefs in ERP assimilation. It motivates followers to enhance their self-worth of putting effort in learning how to apply ERP effectively. Thus, conveying a clear message about the top management's requesting for ERP assimilation increases followers' complying to such request (Milgram 1965).

Proposition $2 c \quad$ Leader's active advocacy of ERP adoption helps to cultivate a culture of learning and development, support and collaboration, and power sharing.

By role modeling, the leader can foster a values system and atmosphere conducive to ERP implementation. Role modeling refers to learning through observing others, though the effect is not just a matter of rote coping but the product of several cognitive processes (Bandura 1997; Locke and Latham 2004). First of all, the way top management team allocates their time is a clear signal to followers about what is important. The top managers who are extremely busy with urgent tasks invest their time in some actions and not in others can influence followers' order of priorities (Popper and Lipshitz 2000). Top management's participation and involvement has been found to be critical for the success of IT projects (e.g., Jarvenpaa and Ives 1991; Beath 1991). Thus, the time devoted by the top management team to participating in the ERP learning sessions, and to listening to and studying ERP project, transmits a message on the central importance of ERP and aspires individuals and group to proactively participate in the project. Hence we have the following proposition:

Proposition $2 d \quad$ Top managers' spending time in learning ERP helps to foster a culture of participative decision making.

Leadership can foster the desired organizational culture by creating intellectual stimulation among followers and sharing knowledge with employees. The leader encourages individual and group learning by motivating followers to question assumptions, be inquisitive, take "intelligent" risks, and come up with creative observations (Bass 1995). To set a role model, top managers should learn from people who have potentially good idea about ERP assimilation, should they be inside or outside the firm (Locke 2004). Due to their networks and rich sources of information, top managers can gain strategic ERP knowledge more easily than followers. By sharing what they know about ERP, leaders intellectually stimulate followers as new ERP knowledge broaden followers' knowledge horizon. Also, such sharing behavior by the leader helps to foster a culture that promotes sharing. Indeed, Armstrong and Sambamurthy (1999) found the significant impact of senior leader's sharing strategic-IT 
related knowledge on IT assimilation. Leader's sharing ERP knowledge also encourages followers to seek ERP knowledge from their sources.

Proposition 2e Top managers' sharing and inquisitive behavior helps to foster a culture that values knowledge sharing and learning.

In addition, leaders can foster a culture of power sharing and tolerance for conflicts by their organizational citizenship behaviors in embracing changes and delegating authorities to lower levels. Organizational citizenship behavior refers to "individual behavior that is discretionary, not directly or explicitly recognized by formal reward system, and that eventually promotes the effective functioning of the organization" (Organ 1988). ERP implementation brings strategic renewal for the firm and involves the restructuring of the organization and reengineering of business processes. It changes the original power balance of key stakeholders, affects the benefits of vested groups and requires followers take on new job functions and responsibilities. Organizational citizenship behaviors can facilitate works in new processes by lubricating the social machinery of organization. Followers with organizational citizenship behaviors are more likely to display a positive reaction toward new processes and responsibilities. Thus, leaders can help to foster the right culture for ERP implementation by motivating followers to organizational citizenship behaviors. When new routines and business processes are established, top managers should set a role model to overcome the resistance to changes by making significant personal sacrifices in the interest of the mission, and to perform above and beyond the call of duty. For example, the leader should sacrifice his/her private interests by being willing to delegate some of his/her power to managers of at lower levels following the ERP implementation. Thus, by their self-sacrificing behaviors, the leader transforms the values, beliefs and attitudes towards power within the organization.

Proposition $2 f \quad$ Top leaders' citizenship behavior helps to foster a culture of power sharing and tolerating conflicts.

The leadership can influence the organizational culture of comprehensive and cross-functional communication by setting up an appropriate learning structure. Learning structure is defined as the institutionalized structural and procedural arrangements allowing organizations to systematically collect, analyze, store, disseminate, and use knowledge relevant to ES assimilation. Examples of learning structure are the setting up of ad hoc committees, special task forces and planning meetings (Vera and Crossan 2004; Trichy and Devanna 1986). The learning mechanisms set up by the top management team enable followers to participate in strategy formulation and to influence values, structures, procedures, systems and products. When followers understand where they and their groups fit into the larger pattern envisioned by top management, they are motivated to offer their ideas (Bass 1995).

In ERP implementation, the firm must integrate the innovative ideas from different functional units. Forming core teams consist of capable key players sharing the values of ERP vision from different business unit allows the firm to integrate ES knowledge and derive solutions to ERP assimilation. Since people in different business units are influenced by their different community cultures and they may approach the same issue from very different perspectives (Schein 1990). Regular meetings among core team members provide them opportunities to understand each other and learn to study the issues on hand from others' perspective. In addition to facilitating the generation of innovative how-to ERP knowledge to apply ERP 
effectively, it also facilitates the reaching of consensus on new business processes and practices following ERP implementation. Indeed, the forming of multi-functional core team is found empirically critical for the ERP success (Robey et al. 2002).

Proposition $2 g$ The leadership helps to cultivate a culture of comprehensive and cross-functional communication.

\section{Discussion and Conclusion}

During the past decade, the huge investment in enterprise resource planning system packages and the significant different adoption results prompt many researchers to search for critical success factors (e.g. Holland and Light 1999; Parr and Shanks 2000; Somers and Nelson 2001; Akkermans and van Helden 2002; Mashari, Mudimigh et al. 2003; Umble, Haft et al. 2003). However, the underlying process of how these factors affect the ERP adoption result remains a largely untapped research area. Our work is motivated by the realization that leadership is the most critical factor that can affect organizational culture and it is important for achieve a fit between its culture and innovation adopted. Due to its nature of integrating processes across functional silos, requiring the sharing of a centralized database and empowering the employees at the front line, ERP implementation may not be compactable with the organizational culture status quo. Hence ERP imposes the adopting firm a great challenge in fostering a set of right values and cultivating a desired organizational culture. As the most powerful agent in the organization, the top management must consciously design and manipulate the firm's culture.

In this paper, we articulate what type of organizational culture is conducive to ERP implementation and matches ERP management philosophy. In addition, along the dimensions of organizational culture, we study what strategic and tactical conducts the leader can take to influence the organization culture. Specifically, we focus on the formulation of a right strategic vision of ERP adoption, advocacy of the vision, role modeling and setting up learning structure by the leader and study these conducts' effect on the dimensions of organizational culture. While we studying the leadership's effect on ERP implementation through fostering the desired organizational culture, we admit the direct effect of leadership on ERP implementation. Since there is a lack of study on the mediating role of organizational culture in the relationship between leadership and ERP implementation, we choose to focus more on the relationship between leadership and organizational culture, and that between organizational culture and ERR implementation.

The work presented here offers several theoretical as well as practical contributions. From the perspective of theory development and advancement, the study posits that the effects of leadership on ERP adoption can be attributable to its ability to influence the organizational culture. In essence, a fresh perspective is offered on how the top management team should perform in ERP adoption by describing a theory that permits predictions regarding what top management teams' strategic and tactical conducts will have positive effects on the organizational culture desired by ERP adoption. From a pragmatic standpoint, this study can inform mangers about the efficacy of strategic and tactical conducts in facilitating the organizational changes involved in ERP implementation. Managers may choose to follow what are proposed in this paper to influence employees' values, cognizance, and motivation to embrace the ERP system. In addition, with the understanding of the underlying process of influencing followers, top managers can choose behaviors suitable to their firm to transform followers from an individual-oriented, hedonistic, rational-economic mode of operation to a 
collective, moral and value-oriented mode of operation. It allows the leader to mobile followers to actions conducive to future IT innovation adoption.

There are some limitations in this study. First, we focus on the influence of top management team and ignore peers' influence. Followers' values and beliefs can be engaged by informal role models and other social influence processes that occur among peers. Studying how leadership is instrumental in the initiation or orchestration of inter-follower processes may shed new lights on leadership's role in ERP adoption. Second, we ignore the follower's characteristics, which may interact with leadership's effect on organizational changes in ERP adoption. In the study conducted by Leonard-Barton and Deschamps (1988), it is found that followers whose characteristics incline them to adopt an innovation will do so without leadership influence. Though this research finding may not be applicable to ERP implementation context due to the complexity and integration nature of the system and discussion on this issue is beyond the scope of current study, it is an interesting future research direction. Third, we did not take national culture issue into our consideration in this paper, though the effect of different mechanisms on organization values in ERP adoption might be different across different national cultural contexts. Studying such difference can offer more guidelines on what the most effective mechanisms for a specific national culture in managing ERP adoption. Finally, additional research would be needed to empirically test the model.

\section{References}

Akkermans, H., and van Helden, K. "Vicious and virtuous cycles in ERP implementation: A case study of interrelations between critical success factors," European Journal of Information Systems (11:1) 2002, pp 35-46.

Al-Mudimigh, A., Zairi, M., and Mashari, M.A. "ERP software implementation: An integrative framework," European Journal of Information Systems (10:4) 2002, pp 216-226.

Armstrong, C.P., and Sambamurthy, V. "Information technology assimilation in firms: The influence of senior leadership and IT infrastructures," Information Systems Research (10:4) 1999, pp 304-327.

Bandura, A. "self-efficacy: Toward a unifying theor of behavioral change," Pychological Review (84:2) 1977, pp 191-215.

Barley, S.R., and Kunda, G. "Design and Devotion - Surges of Rational and Normative Ideologies of Control in Managerial Discourse," Administrative Science Quarterly (37:3), SEP 1992, pp 363-399.

Barney, J.B. "Organizational Culture - Can It Be a Source of Sustained Competitive Advantage," Academy of Management Review (11:3), JUL 1986, pp 656-665.

Bass, B.M. "Leadership - Good, Better, Best," Organizational Dynamics (13:3) 1985, pp 26-40.

Bass, B.M. "Transformational Leadership - Looking at Other Possible Antecedents and Consequences - Comment," Journal of Management Inquiry (4:3), SEP 1995, pp 293-297.

Beath, C.M. "Supporting the Information Technology Champion," MIS Quarterly (15:3), SEP 1991, pp 355-372.

Bharadwaj, A.S. "A resource-based perspective on information technology capability and firm performance: An empirical investigation," MIS Quarterly (24:1), MAR 2000, pp 169-196.

Bingi, P., Sharma, M.K., and Godla, J. "Critical issues affecting an ERP implementation," Information Systems Management, Boston, 1999, pp. 7-14. 
Block, L. "The leadership-culture connection: An exploratory investigation," Leadership \& Organization Development Journal, (24:5/6), pp. 318-334.

Borman, W.C., and Motowidlo, S.J. "Organizational citizenship behavior and contextual performance," Human Performance (10:2) 1997, pp 67-69.

Boynton, A.C., Zmud, R.W., and Jacobs, G.C. "The influence of IT management practice on IT use in large organizations," MIS Quarterly (18:3), Sep 1994, p 299.

Brown, C. and Vessey, I. "ERP implementation practices: Toward a contingency framework," Proceedings of International Conference on Information Systems, 1999.

Cooper, R. B. "The Inertial Impact of Culture on IT Implementation", Information \& Management, (27:1), 1994, pp.17-31

Cooper, R.B., and Zmud, R.W. "Information Technology Implementation Research: A Technological Diffusion Approach," Management Science (36:2), Feb 1990, p 123.

Denison, D.R., and Mishra, A.K. "Toward a Theory of Organizational Culture and Effectiveness," Organization Science (6:2), MAR-APR 1995, pp 204-223.

Dent-Micallef, A., and Powell, T. "Information technology: Strategic necessity of source of competitive advantage? An empirical study on the retail sector of the United States," Canadian Journal of Administrative Sciences-Revue Canadienne Des Sciences De L Administration (15:1), MAR 1998, pp 39-64.

Deshpande, R., and Webster, F.E. "Organizational Culture and Marketing - Defining the Research Agenda," Journal of Marketing (53:1), JAN 1989, pp 3-15.

Gardner, W.L., and Avolio, B.J. "The charismatic relationship: A dramaturgical perspective," Academy of Management Review (23:1), JAN 1998, pp 32-58.

Hurley, R.F., and Hult, G.T.M. "Innovation, market orientation, and organizational learning: An integration and empirical examination," Journal of Marketing (62:3), JUL 1998, pp 42-54.

Jarvenpaa, S.L., and Ives, B. "Executive Involvement and Participation in the Management of Information Technology," MIS Quarterly (15:2), JUN 1991, pp 205-227.

Jarvenpaa, S.L., and Staples, D.S. "Exploring perceptions of organizational ownership of information and expertise," Journal of Management Information Systems (18:1) 2001, pp 151-183 133 pages.

Jung, D.I., and Avolio, B.J. "Effects of leadership style and followers' cultural orientation on performance in group and individual task conditions," Academy of Management Journal (42:2), Apr 1999, pp 208-218.

Klein, K.J., and House, R.J. "On Fire - Charismatic Leadership and Levels of Analysis," Leadership Quarterly (6:2), SUM 1995, pp 183-198.

Leonard-Barton, D., and Deschamps, I. "Managerial influence in the implementation of new technology," Management Science (34:10) 1988, pp 1252-1265.

Locke, E.A., and Latham, G.P. "What should we do about motivation theory? Six recommendations for the twenty-first century," Academy of Management Review (29:3), JUL 2004, pp 388-403.

Lowe, K.B., Kroeck, K.G., and Sivasubramaniam, N. "Effectiveness correlates of transformational and transactional leadership: A meta-analytic review of the MLQ literature," Leadership Quarterly (7:3), FAL 1996, pp 385-425.

Markus, M.L., Tanis, C., and van Fenema, P.C. "Multisite ERP implementations," Communications of the ACM, New York, 2000, pp. 42-46.

Martinsons, M.G., and Chong, P.K.C. "The influence of human factors and specialist involvement on information systems success," Human Relations (52:1), JAN 1999, pp 123-152. 
Mashari, M.A., Mudimigh, A.A., and Zairi, M. "Enterprise resource planning: A taxonomy of critical factors," European Journal of Operational Research (146:2) 2003, pp 352-364.

McKenney, J.L., Mason, R.O., and Copeland, D.G. "Bank of America: The crest and trough of technological leadership," MIS Quarterly (21:3), SEP 1997, pp 321-353.

McLean, E. R. and Smits, S. J. "A role model of IS leadership," Americas Conference on Information Systems, Tempa, FL, 2003.

Mudimigh, A.A., Zairi, M., and Mashari, M.A. "ERP software implementation: An integrative framework," European Journal of Information Systems (10:4) 2001, pp 216-226.

Orlikowski, W.J. "The Duality of Technology - Rethinking the Concept of Technology in Organizations," Organization Science (3:3), AUG 1992, pp 398-427.

Parr, A., and Shanks, G. "A model of ERP project implementation," Journal of Information Technology (15:4), DEC 2000, pp 289-303.

Pawar, B.S., and Eastman, K.K. "The nature and implications of contextual influences on transformational leadership: A conceptual examination," Academy of Management Review (22:1), JAN 1997, pp 80-109.

Podsakoff, P.M., Ahearne, M., and MacKenzie, S.B. "Organizational citizenship behavior and the quantity and quality of work group performance," Journal of Applied Psychology (82:2), APR 1997, pp 262-270.

Popper, M., and Lipshitz, R. "Organizational learning - Mechanisms, culture, and feasibility," Management Learning (31:2), JUN 2000, pp 181-196.

Purvis, R.L., Sambamurthy, V., and Zmud, R.W. "The assimilation of knowledge platforms in organizations: An empirical investigation," Organization Science (12:2), Mar/Apr 2001, pp 117-135.

Robey, D., Ross, J.W., and Boudreau, M.C. "Learning to implement enterprise systems: An exploratory study of the dialectics of change," Journal of Management Information Systems (19:1), SUM 2002, pp 17-46.

Sambamurthy, V., Bharadwaj, A., and Grover, V. "Shaping agility through digital options: Reconceptualizing the role of information technology in contemporary firms," MIS Quarterly (27:2), JUN 2003, pp 237-263.

Sarker, S., and Lee, A.S. "Using a case study to test the role of three key social enablers in ERP implementations," Information \& Management (40:8), 2003, pp. 813-829.

Schein, E.H. Organizational culture and leadership Jossey-Bass, San Francisco, 1985.

Scott, J.E., and Vessey, I. "Managing risks in enterprise systems implementations," Communications of the ACM (45:4), APR 2002, pp 74-81.

Scott-Morton, M.S. "IT-induced business reconfiguration," in: The corporation of the 1990s: Information Technology and Organizational Transformation, M.S. Scott-Morton (ed.), Oxford University Press, Oxford, 1991, pp. 3-23.

Senge, P.M. "The Leader's New Work: Building Learning Organizations," Sloan Management Review), Fall 1990, p 7.

Sharma, R. and Yetton, P. "Th contingent effects of management support and task interdependence on successful information systems implementation," MIS Quarterly (27:4), 2003, pp. 533-555.

Somers, T., and Nelson, K. "The impact of critical success factors across the stages of enterprise resource planning implementations," Hawaii International Conference on Systems Sciences, 2001.

Swanson, E.B. "Information systems innovation among organizations," Management Science (40:9), Sep 1994, pp 1024-1069. 
Umble, E.J., Haft, R.R., and Umble, M.M. "Enterprise resource planning: Implementation procedures and critical success factors," European Journal of Operational Research (146:2) 2003, pp 241-257.

Vera, D., and Crossan, M. "Strategic leadership and organizational learning," Academy of Management Review (29:2), APR 2004, pp 222-240.

Waldman, D.A., Ramirez, G.G., House, R.J., and Puranam, P. "Does leadership matter? CEO leadership attributes and profitability under conditions of perceived environmental uncertainty," Academy of Management Journal (44:1), Feb 2001, pp 134-143.

Walsham, G. "Cross-cultural software production and use: A structurational analysis," MIS Quarterly, 2002, pp. 359-380.

Yukl, G. Leadership in Organizations, (4th ed.) Prentice Hall, Englewook Cliff, NJ, 1998.

Zmud, R.W. "An Examination of 'Push-Pull' Theory Applied to Process Innovation in Knowledge Work," Management Science, 1984, p. 727. 